\title{
Variation in Growth, Colonization of Maize, and Metabolic Parameters of GFP- and DsRed-Labeled Fusarium verticillioides Strains
}

\author{
Lei Wu, R. L. Conner, Xiaoming Wang, Rongqi Xu, and Hongjie Li
}

First, third, and fifth authors: The National Key Facility for Crop Gene Resources and Genetic Improvement/Institute of Crop Science, Chinese Academy of Agricultural Sciences, Beijing 100081; second author: Morden Research and Development Centre, Agriculture and Agri-Food Canada, Morden, Manitoba R6M 1Y5, Canada; and fourth author: Biotechnology Research Institute, Chinese Academy of Agricultural Sciences, Beijing.

Accepted for publication 8 April 2016.

\begin{abstract}
Wu, L., Conner, R. L., Wang, X. M., Xu, R. Q., and Li, H. J. 2015. Variation in growth, colonization of maize, and metabolic parameters of GFP- and DsRed-labeled Fusarium verticillioides strains. Phytopathology 106:890-899.

Autofluorescent proteins are frequently applied as visual markers in the labeling of filamentous fungi. Genes $g f p$ and DsRed were transformed into the genome of Fusarium verticillioides via the Agrobacterium tumefaciensmediated transformation method. The selected transformants displayed a bright green or red fluorescence in all the organelles of the growing fungal mycelia and spores (except for the vacuoles) both in cultures and in the maize (Zea mays) roots they colonized. The results of gene-specific polymerase

chain reaction (PCR) analysis and the thermal asymmetrical interlaced (TAIL)-PCR analysis demonstrated that $g f p$ and DsRed were integrated on different chromosomes of the fungus. Reductions in the colony growth on the plates at $\mathrm{pH} 4.0$ and 5.5 was observed for the green fluorescent protein (GFP)-transformant G3 and the DsRed-transformant R4, but transformants $\mathrm{G} 4$ and $\mathrm{R} 1$ grew as well as the wild-type strain at $\mathrm{pH}$ 4.0. The speed of growth of all the transformants was similar to the wild-type strain at $\mathrm{pH} \geq 7$. The insertion of $g f p$ and DsRed did not alter the production of extracellular enzymes and fumonisin B by $F$. verticillioides. The transformants expressing GFP and DsRed proteins were able to colonize maize roots. However, the four transformants examined produced fewer CFU in the root samples than the wild-type strain during a sampling period of 7 to 28 days after inoculation.
\end{abstract}

Worldwide, Fusarium verticillioides (Sacc.) Nirenberg (syn. F. moniliforme J. Sheld., teleomorph: Gibberella fujikuroi (Sawada) Wollenw.) is an economically important pathogen of maize (Zea mays L.), which incites disease on the ear, stalk, root, and seedlings (Köhl et al. 2015; Kommedahl and Windels 1981). It is also a causal agent of disease in other cereals such as wheat (Triticum aestivum L.), rice (Oryza sativa L.), and sorghum (Sorghum bicolor (L.) Moench) (Kant et al. 2011), as well as cotton (Gossypium hirsutum L.) (Srivastava et al. 2010). In addition to diseases with visible symptoms, $F$. verticillioides also causes endophytic infection of plants without producing any obvious symptoms (Bacon and Hinton 1996). This makes it difficult to detect the interaction between the host and the fungus.

Fluorescent reporter gene labeling of filamentous fungi permits in vitro and in planta monitoring of the growth and development of fungi at cellular and whole-plant levels. This technique is particularly attractive for nondestructive and in situ observation of complex interactions between pathogenic fungi and their hosts (Larrainzar et al. 2005). Green fluorescent protein (GFP) originating from the jelly fish Aequorea victoria Murbach and Shearer has been used to tag a variety of fungal species (Larrainzar et al. 2005; Lorang et al. 2001; Siqueira et al. 2014). DsRed fluorescent protein from the striped mushroom coral Discosoma striata (Anthozoa: Corallimorpharia) is a red fluorescent protein, which offers an alternative color of fluorescence for dual labeling of fungi in association with GFP and allows visualization of different species or strains in a single assay (Dunn et al. 2013; Eckert et al. 2005; Nizam et al. 2010; Sarrocco et al. 2007; Schuster et al. 2015). Fluorescence microscopy can discriminate the fluorescent colors of GFP and DsRed despite a

Corresponding author: H. J. Li; E-mail address: lihongjie@caas.cn

http://dx.doi.org/10.1094/PHYTO-09-15-0236-R

(C) 2016 The American Phytopathological Society small overlap in their emission spectra (Mikkelsen et al. 2003; Nahalkova and Fatehi 2003).

Agrobacterium tumefaciens (E. F. Smith \& Townsend) Connmediated transformation (ATMT) has proven to be an efficient method for the delivery of the reporter genes $g f p$ and DsRed into the genomes of a number of filamentous fungal species (Betts et al. 2007; Grimaldi et al. 2005; Mullins et al. 2001; Oren et al. 2003; van der Does et al. 2008). The obvious advantage of ATMT over other transformation techniques such as electroporation, microprojectile bombardment, and polyethylene glycol (PEG)/CaCl-mediated transformation (Frandsen 2011; Herzog et al. 1996; Sureka et al. 2014 ) is that it provides flexibility in selecting the starting materials. Protoplasts, hyphae, and spores of filamentous fungi are all suitable for ATMT (de Groot et al. 1998). This approach circumvents the preparation of protoplasts, which is an essential and time-consuming step in protoplast-based transformation. The transformation efficiency for ATMT and the frequency of single integration events are higher than other transformation methods. It was reported that genetic transformation via ATMT has been carried out in at least 125 fungal species, which includes ascomycetes, basidiomycetes, zygomycetes, oomycetes, and glomeromycetes (Frandsen 2011).

The fluorescent protein-transformed fungi can be used in nondestructive monitoring of fungus-plant interactions and in functional genomics of fungi (Larrainzar et al. 2005; Michielse et al. 2005). Concerns regarding the use of fluorescent protein-labeled fungi in the study of microbe-plant interactions have arisen based on the potential effects of the expression of such proteins in the host cells. Although no significant difference was observed in the phenotype, mycelial growth, and appearance of the colonies in the DsRed- and GFP-transformed F. oxysporum f. sp. lycopersici (Sacc.) W. C. Synder \& H. N. Hansen (Nahalkova and Fatehi 2003) or Metschnikowia pulcherrima Pitt \& M. W. Mill. (Nigro et al. 1999), variation in colony morphology, growth rate, pathogenicity, and secretion of pectinase was reported in other fungal species (Crespo-Sempere 
et al. 2011; Grunewaldt-Stöcker et al. 2007; Haghighi et al. 2013; Park et al. 2013; Pliego et al. 2009; Rodrigues et al. 2013; Zhang et al. 2008). Such variation was not observed in all the transformants; therefore, there is a need to examine the transformants for selecting the strains that are representative of the wild-type strain before they are used in further study (Lübeck et al. 2002).

In addition to fungal species, GFP-tagged bacterial strains of Ralstonia eutropha (Davis 1969) Yabuuchi et al. 1996 were less competitive than the wild-type strains and the expression of GFP had an impact on 2,4-D affinity in the recipient bacterium (Füchslin et al. 2003). A DsRed-expressing Escherichia coli (Migula 1895) Castellani and Chalmers 1919 strain was markedly smaller than the enhanced GFP (EGFP)-expressing strain (Jakobs et al. 2000). The expression of an improved version of DsRed reduced the competiveness of Pseudomonas fluorescens Migula 1895 F113rif in comparison with the wild-type strain (Dandie et al. 2005).

Fusarium spp. include destructive pathogens that invade many economically important crops over a wide range of environments in the world, and they have been frequently involved in genetic transformation with fluorescent reporter genes. The major purpose of most studies on generating fluorescence-tagged Fusarium spp. has been to visualize the interactions between the fungi and their hosts (Islam et al. 2012; Lagopodi et al. 2002; Nahalkova and Fatehi 2003; Paparu et al. 2009; Sagaram et al. 2007; Sarrocco et al. 2007; Skadsen and Hohn 2004).

F. verticillioides has previously been tagged with GFP for monitoring its infection and growth on maize (Duncan and Howard 2010; Oren et al. 2003; Wilke et al. 2007). In this study, DsRed- and GFP-labeled $F$. verticillioides strains were generated to visualize the colonization of this fungus on maize. The objectives of this study were to examine potential variation in the genetically modified F. verticillioides strains created via ATMT by analyzing their growth, metabolic characteristics, fumonisin production, and colonization on maize root.

\section{MATERIALS AND METHODS}

Fungus and plant material. The $F$. verticillioides strain used in this study was isolated from diseased maize stalks collected from Yayuan County, Jilin Province, P. R. China. Prior to the initiation of the present study, the identity of the fungal strain was confirmed by morphological examination and polymerase chain reaction (PCR) analysis using $F$. verticillioides species-specific internal transcribed spacer sequences (X. M. Wang, unpublished data). The maize inbred line Huangzaosi, which is susceptible to $F$. verticillioides, was used in the inoculation tests of the fungus.

ATMT. The fungus was grown on potato dextrose agar (PDA) plates for 3 days before incubation in the liquid Capek-Dox medium (Puhalla and Spieth 1983) for 7 days at $25^{\circ} \mathrm{C}$ in the dark to promote conidia formation for use in genetic transformation. The plasmids pCAMBGFP (Sesma and Osbourn 2004) and pCAMDsRed (Eckert et al. 2005), which contain the genes $g f p$ and DsRed that are driven by the promoters PgpdA and 35S (CaMV35S), respectively, were used to transform $F$. verticillioides. The vectors were introduced into A. tumefaciens strain AGL-1. A previously described method for ATMT was followed to deliver genes $g f p$ and DsRed into the F. verticillioides genome (Mullins et al. 2001). Briefly, A. tumefaciens cells were increased on yeast extraction peptone medium supplemented with kanamycin and rifampicin $(50 \mu \mathrm{g} \mathrm{ml}-1$ each $)$ at $28^{\circ} \mathrm{C}$ in the dark for $48 \mathrm{~h}$, diluted to an optical density at $600 \mathrm{~nm}\left(\mathrm{OD}_{600}\right)$ of 0.15 , then aseptically transferred to an induction medium (Bundock et al. 1995) containing $200 \mu \mathrm{M}$ acetosyringone and grown for an additional 12 to $15 \mathrm{~h}$. Then, a mixture containing equal volumes of the A. tumefaciens cells $\left(\mathrm{OD}_{600}=0.6\right.$ to 0.7$)$ and the conidial suspension of $F$. verticillioides $\left(1 \times 10^{6}\right.$ conidia $\mathrm{ml}^{-1}, 100 \mu \mathrm{l}$ per plate) were placed on a nitrocellulose filter with $0.45-\mu \mathrm{m}$ pores and incubated for 3 days at $25^{\circ} \mathrm{C}$ on an induction medium containing $5 \mathrm{mM}$ glucose. An excess of $A$. tumefaciens cells was prevented by incubating the filters on the complete medium (Dobinson et al. 1997) containing cefotaxime $(200 \mu \mathrm{M})$. Transformants were repeatedly selected for three rounds on PDA supplemented with hygromycin B $\left(100 \mu \mathrm{g} \mathrm{ml}^{-1}\right)$ prior to selection of transformed monoconidia.

Characterization of the transformants. To confirm the integration of the transfer-DNA (T-DNA) in the genome of $F$. verticillioides, $\mathrm{PCR}$ analyses were conducted with primers that were specific to the target genes $g f p$ and DsRed, as well as the selectable gene hyg for resistance to hygromycin B (Table 1). Genomic DNA of each transformant was extracted from the hyphae that were grown in liquid potato dextrose broth containing hygromycin B $\left(100 \mu \mathrm{g} \mathrm{ml}^{-1}\right)$ for 7 days. PCR was conducted using a $50-\mu 1$ reaction mixture containing $75 \mathrm{ng}$ of template DNA, $10 \mu \mathrm{M}$ each primer, $2.5 \mathrm{mM}$ dNTP, $2.0 \mu \mathrm{l}$ of $10 \times$ PCR buffer, and 1 unit of Taq DNA polymerase. Amplification of the DNA in a PTC-100 thermal cycler (MJ Research Inc.) was programmed at $95^{\circ} \mathrm{C}$ for $10 \mathrm{~min}$; followed by 35 cycles at $95^{\circ} \mathrm{C}$ for $30 \mathrm{~s}, 55,58$, or $56^{\circ} \mathrm{C}$ for $30 \mathrm{~s}$ and $72^{\circ} \mathrm{C}$ for $2 \mathrm{~min}$; and one cycle of extension at $72^{\circ} \mathrm{C}$ for $10 \mathrm{~min}$. The products amplified were visualized following electrophoresis on $2 \%$ agarose gels stained with ethidium bromide.

An epifluorescence microscope ( $\mathrm{CH} 43$; Olympus) was used to examine the expression of the fluorescent proteins GFP (at 470/40 excitation) and DsRed (at 550/25 excitation) in the $10 \mathrm{~F}$. verticillioides transformants. To determine the mitotic stability of transgene integration, conidial suspensions starting from single spores for each of the 10 transformants were sequentially transferred onto hygromycin B-free PDA for six rounds at 7-day intervals. The final generations of conidia were regrown on PDA containing hygromycin B (100 $\mu \mathrm{g} \mathrm{ml}^{-1}$ ) to confirm the fluorescence in the transformants.

Analysis of $\boldsymbol{F}$. verticillioides genomic sequences flanking the T-DNA. To determine the insertion sites of the target genes $g f p$ and DsRed in the genomes of the transformants, thermal asymmetrical interlaced (TAIL)-PCR was conducted to clone the genomic sequences flanking the inserted T-DNA in each transformant.

TABLE 1. Primers used in analysis of genes $g f p$, DsRed, and hyg and in thermal asymmetrical interlaced polymerase chain reaction

\begin{tabular}{|c|c|c|c|}
\hline Primer $^{\mathrm{z}}$ & Specific for & Sequence & Reference \\
\hline EGFP-F & $G f p$ & 5'-TAAACGGCCACAAGTTCA-3' & Eckert et al. 2005 \\
\hline EGFP-R & $\ldots$ & 5'-TGCTCAGGTAGTGGTTGT-3' & $\ldots$ \\
\hline DsRed-F & DsRed & 5'-ACTCCTCCGAGGACGTCATCAA-3' & Eckert et al. 2005 \\
\hline Hyg-8F & Hyg & 5'-GCAGACAGGAACGAGGACAT-3' & Xu et al. 2010a \\
\hline Hyg-8R & $\ldots$ & 5'-GCTCCATACAAGCCAACCAC-3' & $\ldots$ \\
\hline \multicolumn{4}{|c|}{ 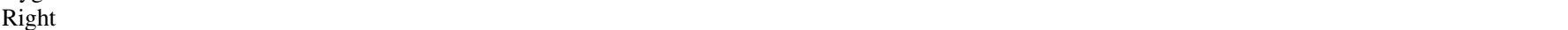 } \\
\hline RB-1 & $\ldots$ & 5'-CGTGACTGGGAAAACCCTGGCGTT-3' & Mullins et al. 2001 \\
\hline \multicolumn{4}{|c|}{ 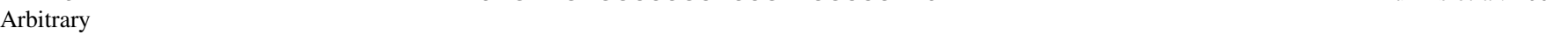 } \\
\hline $\mathrm{AD}-\mathrm{C}$ & $\ldots$ & 5'-ACGATGGACTCCAGAG-3' & Mullins et al. 2001 \\
\hline AD-5 & $\ldots$ & 5'-ACGATGGACTCCAGAGCGGCCGCBHNDNNNGACC-3' & $\mathrm{Xu}$ et al. 2010a \\
\hline
\end{tabular}

${ }^{\mathrm{z}}$ EGFP $=$ enhanced green fluorescent protein, Right $=$ right border primers, and Arbitrary $=$ arbitrary degenerate primers. 
Amplification of the DNA was carried out using a previously described program with the primers specific for the right (RB-1, -2, and -3) and the arbitrary degenerate primers (AD-C and -5) (Table 1). The tertiary TAIL-PCR products of each transformant with the highest amplification intensity were purified and sequenced using the innermost specific primer RB-3 as the sequencing primer. The sequences were aligned against $F$. verticillioides genomic sequence (https://www. broadinstitute.org/scientific-community/science/projects/fungalgenome-initiative/fungal-genomics).

Colony growth of the transformants at various $\mathrm{pH}$ values. Freshly increased conidia of each transformant and the wild-type cultures of $F$. verticillioides were diluted with sterile distilled water to a concentration of $10^{6}$ conidia $\mathrm{ml}^{-1}$. Plates $(9 \mathrm{~cm}$ in diameter) were filled with $20 \mathrm{ml}$ of PDA each and adjusted to $\mathrm{pH}$ values of $4.0,5.5,7,8.5,10.0$, and 11.5. Conidial suspension (5 $\mu \mathrm{l}$ each) were loaded on the center of each PDA plate. Each $\mathrm{pH}$ treatment consisted of three replicates with a single plate each using a randomized complete block design. The plates were incubated at $25^{\circ} \mathrm{C}$ under a photoperiod of $12 \mathrm{~h}$ of darkness and $12 \mathrm{~h}$ of light provided by incandescent light. Two diameters of growing colonies in perpendicular directions were measured daily for seven consecutive days following inoculation. This experiment was conducted twice.

Quantification of the mycotoxin fumonisin B in the transformants. Three replicated cultures initiated from the same single-spore cultures of each transformant and the wild-type culture were used in enzyme-linked immunosorbent assay (ELISA) for quantifying of fumonisin $\mathrm{B}(\mathrm{FB})$. Each transformant $\left(1 \times 10^{6}\right.$ conidia $\mathrm{ml}^{-1}, 5 \mu \mathrm{l}$ each) was transferred into a $20-\mathrm{ml}$ scintillation vial containing $5 \mathrm{~g}$ of autoclaved cracked maize kernels and $5 \mathrm{ml}$ of water. After incubation at $27^{\circ} \mathrm{C}$ for 7 days in the dark, $10 \mathrm{ml}$ of acetonitrile/water (1:1) containing $5 \%$ formic acid was added to each vial. The mixtures were shaken vigorously to disrupt the fungal colonies and then incubated on a rocking shaker set at $220 \mathrm{rpm}$ for $3 \mathrm{~h}$ (Glenn et al. 2008). The extracts were diluted 1,000-fold with acetonitrile/water (3:7) containing $1 \%$ formic acid (vol/wt). Then, the diluted samples were subjected to competitive ELISA using a Beacon FB plate kit. The ELISA plates were read with a fluorimeter RT-2100e (Rayto Life and Analytical Sciences Co., Ltd.). The quantification of FB was performed with three replicates for each transformant and the wild-type strain and the experiment was carried out twice using a randomized complete block design.

Metabolism of extracellular enzymes in the transformants. Freshly increased microconidia $\left(10^{5}\right.$ microconidia $\left.\mathrm{ml}^{-1}\right)$ were inoculated onto agar plates of Czapek-Dox media supplemented separately with either nonfat-dried milk $(1 \%$, wt/vol $)$, pectin $(1 \%$, $\mathrm{wt} / \mathrm{vol})$, starch $(0.1 \%, \mathrm{wt} / \mathrm{vol})$, or carboxymethyl cellulose $(0.5 \%$, $\mathrm{wt} / \mathrm{vol}$ ) as the carbon source prior to incubation at $25^{\circ} \mathrm{C}$ for 3 days, as described previously (Di Pietro and Roncero 1998). Colonies were stained using different methods and the ratios of transparencies were individually determined to measure the activity of the extracellular enzymes protease, pectinase, amylase, and cellulase (Xu et al. 2010a). The experiments for each extracellular enzyme consisted of three replicates with a single plate each and the experiment was conducted twice using a randomized complete block design.

Systemic colonization of $\boldsymbol{F}$. verticillioides strains in maize. Seeds of the susceptible maize inbred line Huangzaosi were washed with running water, surface sterilized in $75 \%$ alcohol for $5 \mathrm{~min}$ and $0.4 \%$ sodium hypochlorite for 15 to $20 \mathrm{~min}$, and rinsed with sterile distilled water. Then, the sterilized seeds were immersed in conidial suspensions $\left(10^{8}\right.$ conidia $\left.\mathrm{ml}^{-1}\right)$ for $30 \mathrm{~min}$ to separately inoculate with each transformed strain either labeled with the fluorescent reporter genes $g f p$ and DsRed or the nonlabeled wild-type strain. The seed were dried overnight in a laminar flow hood and sown in pots $(15 \mathrm{~cm}$ in diameter) containing sterilized vermiculite. Plants were grown in a greenhouse at $25 \pm 2^{\circ} \mathrm{C}$ with a photoperiod of $16 \mathrm{~h}$ of light and $8 \mathrm{~h}$ of darkness. Mock-inoculated seeds, which were immersed in distilled water without any fungal conidia for 30 min, were used as the control. Each experimental unit of $F$. verticillioides strain inoculation included two pots containing a total of four plants per pot at each sampling date and had three replications. A Microtome (MTH-1) was used to prepare root cross sections. Infection and colonization by the fluorescent protein-labeled $F$. verticillioides strains of the maize roots were observed using a confocal laser-scanning microscope (model Leica TCS SP2; Leica Microsystems $\mathrm{GmbH}$ ) under the emission wavelengths of 488/ $507 \mathrm{~nm}$ (GFP) and 558/583 nm (DsRed).

Both inoculated and mock-inoculated maize roots were sampled at $7,14,21$, and 28 days after inoculation (DAI) to determine the number of CFU, as previously described (Li et al. 2008). The roots from four plants on each sampling date were removed from the soil, washed thoroughly with tap water, and surface sterilized for $15 \mathrm{~min}$ in $0.5 \%$ ( vol/vol) $\mathrm{NaClO}$ solution. The samples were rinsed several times with sterile deionized water and dried on sterile filter papers. Then, the samples were weighed prior to grinding in $10 \mathrm{ml}$ of sterile deionized water using a Fast-Prep-24 Instrument (MP Biomedicals, Inc.) at high speed for $1 \mathrm{~min}$. The homogenized tissue suspensions were then filtered through two layers of Whatman number 1 filter paper and diluted 20-fold with sterile deionized water. The diluted samples were separately spread with a sterile glass rod on sugar-free agar plates.

Each sample consisted of three replicate plates inoculated with $50 \mu \mathrm{l}$ of tissue suspensions. All of the plates were incubated at $25^{\circ} \mathrm{C}$ in the dark for 3 days. The colonies of $F$. verticillioides on each plate were counted to determine the CFU per gram of root for each strain. This study was performed twice using a randomized complete block design.

Statistical analysis. Analysis of variance (ANOVA) was conducted using the General Linear Model procedure in the Statistical Analysis Software (SAS) package (version 9.1; SAS Institute). Using Dunnett's $t$ test or Fisher's least significant difference (LSD) test (Steel and Torrie 1960), means of the fluorescent protein-labeled strains were compared with that of the wild-type strain to determine the significance of difference for the parameters at $P<0.05$. Prior to ANOVA, a test of the homogeneity of variance was performed for all the parameters. Because the strain-test interactions for all the parameters were not significant, data from the two tests were pooled together for the statistical analyses.

\section{RESULTS}

ATMT of $\boldsymbol{F}$. verticillioides and expression of fluorescence in the transformants. By means of ATMT, the $g f p$ and DsRed genes were delivered into $F$. verticillioides genome and transformants were obtained following three rounds of selection on hygromycin B-containing PDA plates. The final hygromycin B-resistant transformants were increased on hygromycin B-free PDA plates. In the five randomly selected GFP-labeled strains G1, G2, G3, G4, and G5, a bright green fluorescence accumulated uniformly in conidia and hyphae (Fig. 1A, B, and C). Fluorescence was observed in all the structures within the cell, including the nucleus, cytoplasm, and cell wall, with the exception of vacuoles, which appeared as dark areas or with a faint fluorescence in the fungal cytoplasm. The DsRed-labeled strains R1, R2, R3, R4, and R5 displayed bright red fluorescence, and the patterns of red fluorescence in the different structures of cells were similar to those in the GFP-labeled strains (Fig. 1D and E). These observations indicated that genes $g f p$ and DsRed were strongly expressed in all the fungal tissues of the transformed strains examined. In some microconidia, the expression of red fluorescence was not uniform. The intensity of fluorescence in small foci areas inside the microconidia was brighter than other parts of the cell (Fig. 1F). When the transformants were continuously exposed to blue or green fluorescent light, the fluorescence of the GFP- and DsRed-transformants was quenched in approximately $15 \mathrm{~min}$. The fluorescence in newly developed 
conidia and conidiophores was quenched more rapidly than in the mature hyphae and conidia. The fluorescence in the vacuoles of the newly formed hyphae was quenched more slowly than in other parts of the hyphae (Fig. $1 \mathrm{G}$ and $\mathrm{H}$ ).

Characterization of the transformants. Using the primer pairs specific for the selectable gene hyg, a fragment 800 bp in length was amplified from all the strains transformed either with $g f p$ or DsRed (Fig. 2A). The $g f p$ - and DsRed-specific primers amplified the diagnostic bands (543 and $579 \mathrm{bp}$, respectively) only in the corresponding transformants and the positive controls (Fig. 2B and C). Both gene-specific primers did not amplify any product from the wild-type strain. These amplification results confirmed the integration of the target genes $g f p$ and DsRed in the F. verticillioides genome.

Evaluation of mitotic stability of transgene integration indicated that the expression of genes $g f p$ and DsRed was stable in all the transformants examined. This was confirmed by the fact that all the transformants displayed a similar intensity of fluorescence in conidia and hyphae as the corresponding original strains after six rounds of subculturing on hygromycin B-free PDA.
Analysis of the flanking T-DNA sequences. TAIL-PCR was performed to amplify the genomic sequences flanking the insertion sites of the T-DNA in the transformants. Using the arbitrary primer $\mathrm{AD}-5$ and the right-border-specific primers (RB-1, -2, and -3), the right junction fragments of T-DNA insertion were amplified in 4 of the 10 transformants analyzed (i.e., G3, G4, R1, and R4) (Table 2). The TDNA was inserted into chromosomes 7 and 5 in the GFP transformants G3 and G4, respectively. No functional gene was detected near the flanking sequences of the T-DNA in the two transformants. The TDNA of the DsRed-transformant R1 was located on chromosome 5 in the coding region of FVEG09252.5, which is a nitrogen fixation protein NifU containing two domains, NifU-like $\mathrm{N}$ terminal domain and FeS cluster assembly scaffold IscU (Fig. 3). The T-DNA of DsRed-transformant R4 was located on chromosome 8 and the closest protein was a hypothetical protein. These four transformants with known insertion sites were used in further characterization studies.

Colony growth of the transformants at different $\mathrm{pH}$ values. The growth of the colonies on PDA with $\mathrm{pH}$ values ranging from 4.0 to 11.5 varied among the transformants. The colonies of the GFP-labeled strain G3 grew significantly slower than the wild-type
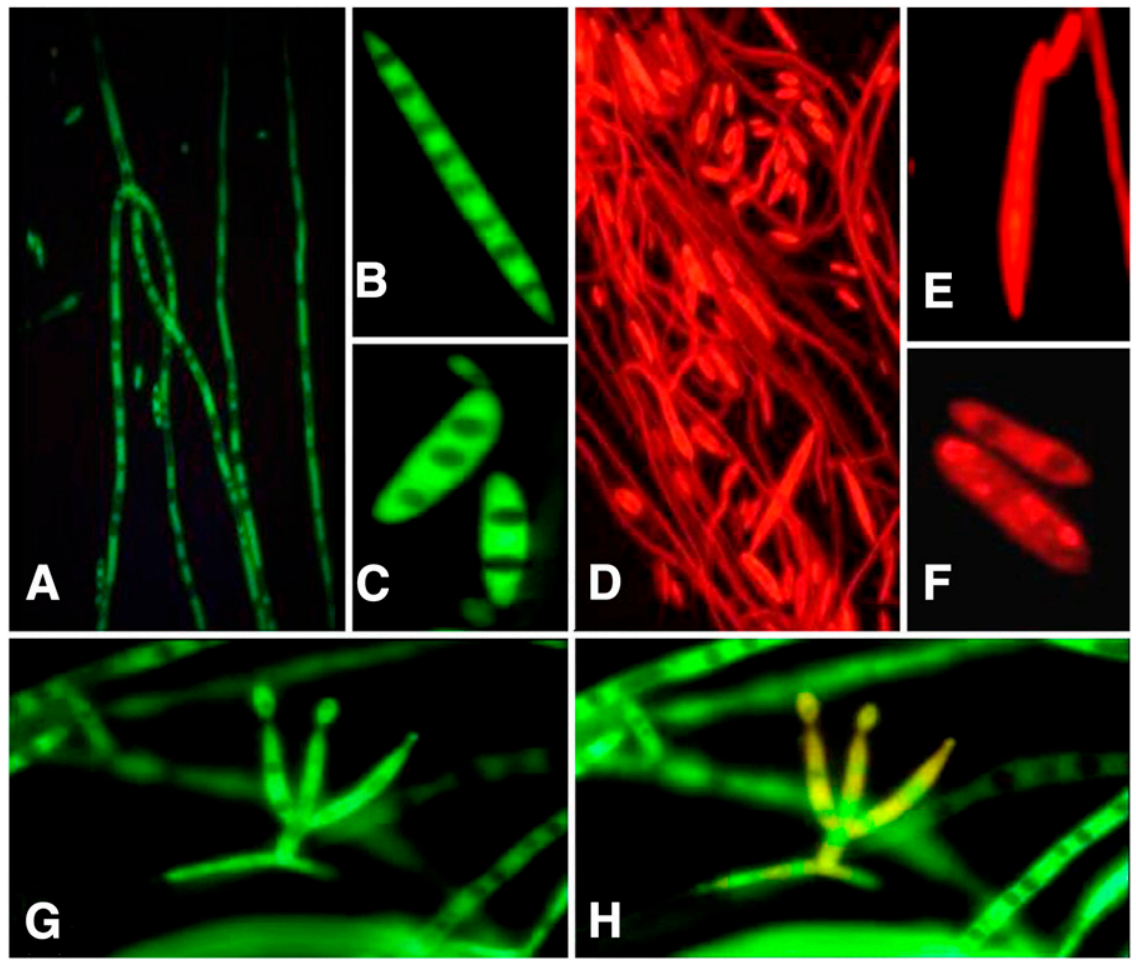

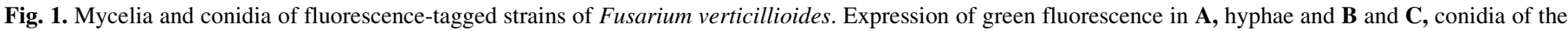

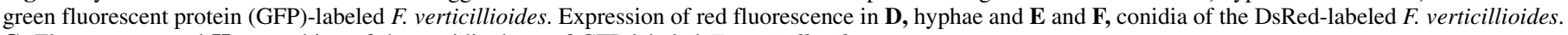
$\mathbf{G}$, Fluorescence and $\mathbf{H}$, quenching of the conidiophore of GFP-labeled $F$. verticillioides.

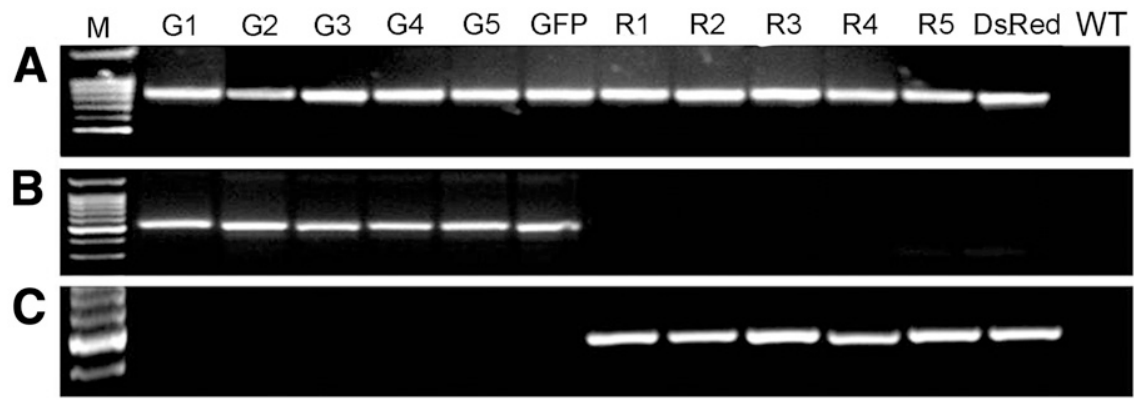

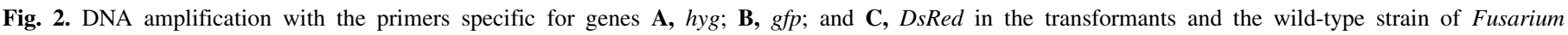

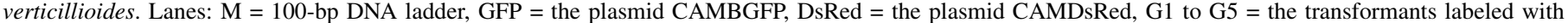
green fluorescent protein $(\mathrm{GFP}), \mathrm{R} 1$ to R5 = the transformants labeled with DsRed, and WT = the wild-type F. verticillioides. 
strain at $\mathrm{pH} 4$ and 8.5 , as indicated by their smaller colony diameters and daily colony growth. The colony diameter of strain G3 was significantly greater than that of the wild-type strain at $\mathrm{pH} 11.5$ (Table 3). The colony diameter of G3 was slightly smaller than the wild-type strain at $\mathrm{pH} 5.5$ but the daily increase of colony was significantly less than the wild-type strain. The colony diameter of strain G4 was significantly less at pH 5.5 than the wild-type strain but greater at $\mathrm{pH}$ 11.5. No significant differences from the wildtype strain were observed for the colony diameters and daily increase of strain G4 at pH 4.0, 7.0, 8.5, or 10.0. The growth characteristics of strain R1 were not significantly different from those of the wild-type strain at all $\mathrm{pH}$ values, except for its greater colony diameters at $\mathrm{pH}$ 10.0 and 11.5. Strain R4 grew more slowly than the wild-type strain at $\mathrm{pH} 4$ and 5.5 but its colony diameter and daily increase parameters did not differ significantly from the wild-type strain at $\mathrm{pH} 7$ to 11.5. Regardless of the transformation for GFP or DsRed proteins, the growth of all strains at $\mathrm{pH} 4.0$ was significantly slower than at other $\mathrm{pH}$ values but the colony expansion at $\mathrm{pH} 11.5$ for all strains was significantly greater than at the other $\mathrm{pH}$ values $(P<0.05)$. The colony diameter and daily increase for the $F$. verticillioides strains at $\mathrm{pH} 5.5$ to 10.0 were not significantly different from each other in most cases.
Quantification of mycotoxin FB in the transformants. Using the ELISA method, the production of FB in the transformants and the wild-type strain was quantified. The titers of FB in the transformants G3, G4, R1, and R4 ranged from 537.1 to $684.6 \mathrm{ng} \mathrm{ml}^{-1}$ (Table 4). Although variation in the titers of FB was observed among the strains tested, no significant differences were detected among the individual transformants and the wild-type strain. The color of crude extracts of fumonisin differed among the transformants. The GFP-transformed strain G3 and the DsRed-transformed strains R1 and R4 had obviously darker-colored extracts compared with the wild-type strain and strain G4, which were not different from each other (Fig. 4). This indicates that the metabolism of the pigment might be influenced by the T-DNA insertion site.

Metabolism of extracellular enzymes in the transformants. When grown on the Czapek-Dox plates supplemented separately with either nonfat-dried milk, pectin, starch, or carboxymethyl cellulose, the size of the clear zones around the colonies of all the transformants were similar to those of the wild-type strain. Although the diameters of the transparent zones varied along with the diameters of the colonies on each medium, the ratios of the zones of transparency to the fungal diameters for the transformants were

TABLE 2. Sequences flanking the transfer-DNA of the green fluorescent protein (GFP)-transformed strains G3 and G4 and the DsRed-transformed strains R1 and R4 inserted in the Fusarium verticillioides genome

\begin{tabular}{|c|c|c|c|c|c|c|c|c|}
\hline Strain $^{\mathrm{x}}$ & Location & $\mathrm{Chr}^{\mathrm{y}}$ & Score & $\begin{array}{l}\text { Highest } E \\
\text { value }\end{array}$ & $\begin{array}{c}\text { Number of } \\
\text { identities }(\%)\end{array}$ & $\begin{array}{c}\text { Number of } \\
\text { positives }(\%)\end{array}$ & Closest related protein ${ }^{z}$ & $\begin{array}{c}\text { Presence of conserved } \\
\text { domain }\end{array}$ \\
\hline G3 & $\begin{array}{l}\text { F. verticillioides } 7600 \\
\text { (FV3): Supercontig } 8 \text { : } \\
\text { 620182-620199+ }\end{array}$ & 7 & $36.1753(18)$ & 4.70259 & $18 / 18(100)$ & $18 / 18(100)$ & NO & $\begin{array}{l}\text { No protein domains } \\
\text { found }\end{array}$ \\
\hline G4 & $\begin{array}{l}\text { F. verticillioides } 7600 \\
\text { (FV3): Supercontig 12: } \\
\text { 1070297-1070403 }\end{array}$ & 5 & $133.311(67)$ & $2.27872 \mathrm{E}-29$ & 98/107 (91) & 98/107 (91) & NO & $\begin{array}{l}\text { No protein domains } \\
\text { found }\end{array}$ \\
\hline R1 & $\begin{array}{l}\text { F. verticillioides } 7600 \\
\text { (FV3): Supercontig 12: } \\
\text { 1069721-1070297- }\end{array}$ & 5 & $1146.29(578)$ & 0.0 & $630 / 656(96)$ & $630 / 656(96)$ & $\begin{array}{l}\text { FVEG_09252.5 } \text { ne9.tiogen fixation } \\
\text { nitrotein NifU }\end{array}$ & $\begin{array}{l}\text { NifU-like } \mathrm{N} \text { terminal } \\
\text { domain; iscU: FeS } \\
\text { cluster assembly } \\
\text { scaffold IscU }\end{array}$ \\
\hline $\mathrm{R} 4$ & $\begin{array}{l}\text { F. verticillioides } 7600 \\
\text { (FV3): Supercontig 9: } \\
\text { 117768-117785 }\end{array}$ & 8 & $36.1753(18)$ & 3.92044 & $18 / 18(100)$ & $18 / 18(100)$ & $\begin{array}{l}\text { FVEG_07208.5 } \\
\text { hypothetical protein }\end{array}$ & $\begin{array}{l}\text { Mitochondrial carrier } \\
\text { protein }\end{array}$ \\
\hline
\end{tabular}

$\mathrm{x}$ Transformant strain.

y Chromosome.

${ }^{\mathrm{z}}$ https://www.broadinstitute.org/scientific-community/science/projects/fungal-genome-initiative/fungal-genomics.

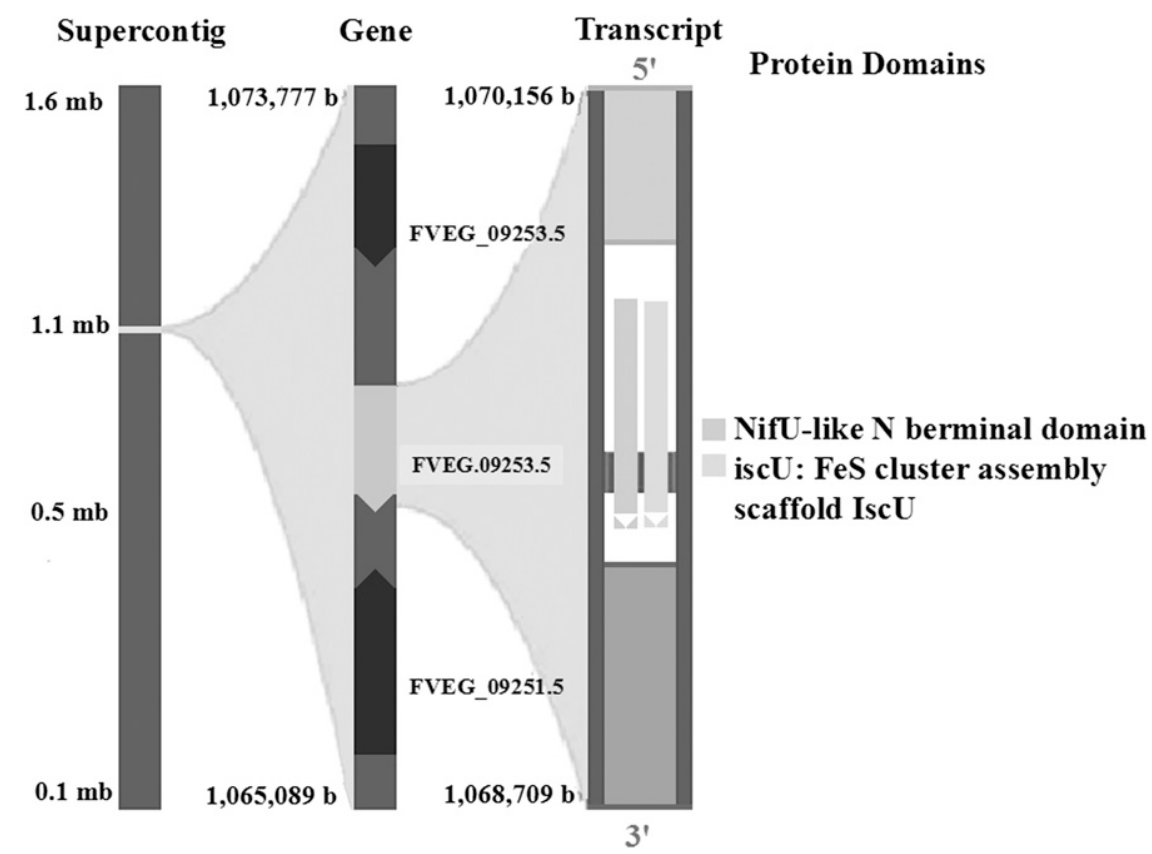

Fig. 3. Insertion of the transfer-DNA in the DsRed-transformed strain R1 in the coding sequence of gene FVEG6.09252.5. 
not significantly different from that of the wild-type strain based on Fisher's LSD test (Fig. 5). This indicates that the production of enzymes such as protease, pectinase, amylase, and cellulase in the transformants was similar to the wild-type strain. The fungal colonies grew faster on the Czapek-Dox plates supplemented with pectin and the fungal strains produced larger zones of transparencies on the plates with pectin than on the plates with nonfat-dried milk, starch, or carboxymethyl cellulose (data not shown).

Colonization of GFP- and DsRed-tagged $F$. verticillioides strains in maize roots. The $F$. verticillioides strains labeled with GFP or DsRed were able to colonize the roots of maize inbred line Huangzaosi (Fig. 6). Colonization of the fungus on the roots was readily observed at the early stage of infection; however, few fungal mycelia were observed in the root tissues with dark-brown lesions at later stages of infection.

Colonies of $F$. verticillioides were recovered from the roots that had been inoculated separately with each of the transformants as well as the wild-type strain. The quantities of pathogen mycelia colonizing the maize roots were evaluated based on the number of CFU (Table 4). The $\mathrm{CFU}$ values for all the strains decreased with the days after inoculation. In the 7-DAI root samples, colonization by the GFP- and DsRedlabeled and wild-type strains of $F$. verticillioides was detected. However, variation in terms of CFU was observed among different strains of the fungus. Strains G3 and G4 produced significantly lower $\mathrm{CFU}$ values than the wild-type strain $(P<0.05)$. All the $\mathrm{CFU}$ values for the GFP-labeled strains at 14,21, and 28 DAI were significantly less than those of the wild-type strain at the corresponding sampling dates $(P<0.01)$. Similarly, the CFU values for the DsRed-labeled strains R1 and R4 were all significantly less than those of the wild-type strain at different sampling dates $(P<0.01)$. No fungal colonies were recovered from the mock-inoculated samples.

\section{DISCUSSION}

Autofluorescent reporter proteins such as GFP and DsRed can be visualized directly without the need of external substrates or cofactors of proteins. Therefore, autofluorescent reporter gene labeling of filamentous fungi is a powerful tool for the in situ monitoring of the behavior of pathogenic and endophytic fungi in their host tissues and for understanding plant-microbe interactions and microbe ecology in a nondestructive way (de Groot et al. 1998; Larrainzar et al. 2005; Lorang et al. 2001). The ATMT method does not require work with protoplasts; therefore, it is more often used to deliver the reporter genes into the fungal genomes compared with electroporation, PEG, or particle bombardment-mediated transformation methods (Frandsen 2011). Because ATMT is also widely used as an effective means for targeted mutagenesis studies (Michielse et al. 2005) and some autofluorescent proteins tend to form aggregates, which may have an impact on the fitness of certain recipients (Dandie et al. 2005; Füchslin et al. 2003; Jakobs et al. 2000), it is necessary to thoroughly examine the phenotypic performances of transformants before they are used in the studies on microbe-plant interactions.

In view of its importance as a causal pathogen of various diseases of maize and other cereal crops, $F$. verticillioides has previously been tagged with GFP (Duncan and Howard 2010; Oren et al. 2003; Wilke et al. 2007) and other fluorescent proteins such as AmCyan, ZsGreen, ZsYellow, and AsRed (Bourett et al. 2002) for studies on its interactions with the host crops. In the current study, the transformants were obtained that expressed either GFP or DsRed proteins. The fluorescent proteins not only were obvious in all the organelles within the fungal cells (except for the vacuoles) in cultures but also were observed in the fungal cells inside the maize root tissues. Usually, the expression of fluorescence in the recipient cells was even throughout the spores and hyphae. However, small, brightly colored foci were present in some DsRed-transformed microspores, resulting in uneven distribution of the red fluorescence (Fig. 1F). These bright foci of red fluorescence may have resulted from the formation of oligomers or high molecular weight aggregates, which represent the molecular characteristics of DsRed (Baird et al. 2000; Bourett et al. 2002; Jakobs et al. 2000).

It was noticed that the fluorescence of GFP and DsRed proteins became photobleached when the transformants were exposed to

TABLE 3. Comparison of the colony diameters at day 7 and daily growth among the transformants and the wild type (WT) of Fusarium verticillioides at different $\mathrm{pH}$ values ${ }^{\mathrm{z}}$

\begin{tabular}{|c|c|c|c|c|c|c|c|c|c|c|c|c|c|c|}
\hline \multirow[b]{2}{*}{ Strain } & \multicolumn{7}{|c|}{ Colony diameter $(\mathrm{cm})$} & \multicolumn{7}{|c|}{ Daily increase $(\mathrm{cm})$} \\
\hline & $\mathrm{pH} 4.0$ & $\mathrm{pH} 5.5$ & $\mathrm{pH} 7.0$ & $\mathrm{pH} 8.5$ & $\mathrm{pH} 10.0$ & pH 11.5 & $\mathrm{LSD}_{0.05}$ & $\mathrm{pH} 4.0$ & $\mathrm{pH} 5.5$ & pH 7.0 & $\mathrm{pH} 8.5$ & $\mathrm{pH} 10.0$ & $\mathrm{pH} 11.5$ & $\mathrm{LSD}_{0.05}$ \\
\hline WT & $6.33 \mathrm{c}$ & $7.93 \mathrm{~b}$ & $7.79 \mathrm{~b}$ & $7.79 \mathrm{~b}$ & $7.66 \mathrm{~b}$ & $8.78 \mathrm{a}$ & 0.448 & $0.86 \mathrm{c}$ & $1.13 \mathrm{~b}$ & $1.09 \mathrm{~b}$ & $1.11 \mathrm{~b}$ & $1.11 \mathrm{~b}$ & $1.31 \mathrm{a}$ & 0.088 \\
\hline G3 & $5.98 * \mathrm{e}$ & $7.55 \mathrm{bc}$ & $7.86 \mathrm{~b}$ & $6.84^{*} \mathrm{~d}$ & $7.30 \mathrm{c}$ & $9.00 * \mathrm{a}$ & 0.394 & $0.79 * \mathrm{~d}$ & $1.02 * \mathrm{~b}$ & $1.07 \mathrm{~b}$ & $0.91 * \mathrm{c}$ & $1.00 \mathrm{~b}$ & $1.29 \mathrm{a}$ & 0.075 \\
\hline G4 & $6.41 \mathrm{~d}$ & $7.47 * \mathrm{c}$ & $7.82 \mathrm{bc}$ & $7.97 \mathrm{~b}$ & $8.09 \mathrm{~b}$ & $9.00 * \mathrm{a}$ & 0.400 & $0.84 \mathrm{~d}$ & $1.01 * \mathrm{c}$ & $1.07 \mathrm{bc}$ & $1.11 \mathrm{bc}$ & $1.16 \mathrm{~b}$ & $1.32 \mathrm{a}$ & 0.096 \\
\hline $\mathrm{R} 1$ & $6.45 \mathrm{~d}$ & $7.59 \mathrm{c}$ & $7.73 \mathrm{c}$ & $7.83 \mathrm{c}$ & $8.41 * b$ & $9.00 * \mathrm{a}$ & 0.405 & $0.88 \mathrm{~d}$ & $1.05 \mathrm{c}$ & $1.06 \mathrm{c}$ & $1.08 \mathrm{c}$ & $1.19 \mathrm{~b}$ & $1.32 \mathrm{a}$ & 0.087 \\
\hline $\mathrm{R} 4$ & $6.10 * \mathrm{e}$ & $7.28 * \mathrm{~d}$ & $8.12 \mathrm{~b}$ & $7.75 \mathrm{c}$ & $7.83 \mathrm{bc}$ & $8.86 \mathrm{a}$ & 0.297 & $0.82 * \mathrm{~d}$ & $1.00^{*} \mathrm{c}$ & $1.12 \mathrm{~b}$ & $1.08 \mathrm{~b}$ & $1.10 \mathrm{~b}$ & $1.29 \mathrm{a}$ & 0.050 \\
\hline $\mathrm{MSD}_{0.05}$ & 0.150 & 0.454 & 0.609 & 0.757 & 0.519 & 0.142 & & 0.026 & 0.084 & 0.125 & 0.142 & 0.130 & 0.059 & \\
\hline
\end{tabular}

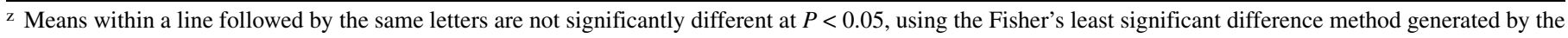
general linear model (GLM) procedure in the Statistical Analysis Software (SAS) package; * indicates means $(n=6)$ significantly different from the WT strain at $P<0.05$, using the Dunnett's $t$ test generated by the GLM procedure in SAS. MSD = minimum significant difference according to the Dunnett's $t$ test. Tests of homogeneity of variance indicated that the strain by test interaction was not significant; therefore, the means for colony diameter and daily increase were calculated from the data sets of the two tests.

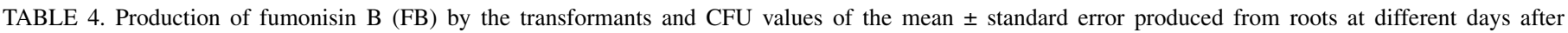
inoculation of the transformants and the wild-type (WT) strain of Fusarium verticillioides

\begin{tabular}{|c|c|c|c|c|c|}
\hline \multirow[b]{2}{*}{ Strain } & \multirow[b]{2}{*}{$\mathrm{FB}\left(\mathrm{ng} \mathrm{ml} \mathrm{l}^{-1}\right)$} & \multicolumn{4}{|c|}{$\mathrm{CFU}^{\mathrm{z}}$} \\
\hline & & Day 7 & Day 14 & Day 21 & Day 28 \\
\hline WT & $589.9 \pm 50.4$ & $3,312.4 \pm 61.6$ & $3,020 \pm 249.5$ & $773.3 \pm 108.2$ & $719.7 \pm 111.5$ \\
\hline G3 & $584.7 \pm 42.9$ & $2,051.3 \pm 258.5 * *$ & $686.4 \pm 69.4 * *$ & $492.1 \pm 20.9 * *$ & $258.8 \pm 41.9 * *$ \\
\hline G4 & $562.9 \pm 36.2$ & $1,690.6 \pm 153.3 * *$ & $1,655.8 \pm 60.8 * *$ & $149.3 \pm 11.9 * *$ & $142.9 \pm 23.3^{* *}$ \\
\hline $\mathrm{R} 1$ & $537.1 \pm 32.9$ & $2,123.1 \pm 43.7 * *$ & $786.4 \pm 29.5^{* *}$ & $135.1 \pm 15.6^{* *}$ & $104.3 \pm 8.7 * *$ \\
\hline $\mathrm{R} 4$ & $684.6 \pm 37.4$ & $825.8 \pm 30.7 * *$ & $450.3 \pm 22.7 * *$ & $378.1 \pm 21.7 * *$ & $88.1 \pm 14.1 * *$ \\
\hline $\mathrm{MSD}_{0.05}$ & 149.09 & 577.14 & 444.22 & 125.33 & 92.55 \\
\hline
\end{tabular}

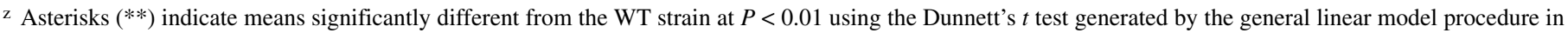
the Statistical Analysis Software package. MSD = minimum significant difference according to the Dunnett's $t$ test. 
continuous light. This creates a problem for long-term imaging when using such transformants in the visualization of the fungusplant interactions. Bourett et al. (2002) reported that a reef coral fluorescent protein ZsGreen from Zoanthus sp. can be visualized under low laser powers for at least $60 \mathrm{~min}$ when it was transferred into F. verticillioides and Magnaporthe grisea (T. T. Hebert) M. E. Barr. The ZsGreen-transformed $F$. verticillioides has been used to study the colonization of $F$. verticillioides on the maize kernels (Duncan and Howard 2010).

The insertion of GFP was reported to have an impact on the production of mycotoxins and extracellular enzymes. In an EGFP transformant of Aspergillus carbonarius (Bainier) Thom, ochratoxin A production was increased (Crespo-Sempere et al. 2011). Although the transformation of GFP in Guignardia citricarpa Kiely did not change the secretion of certain hydrolytic enzymes, such as protease, lipase, and esterase, 10 of the 15 transformants produced lower amounts of pectinase (Rodrigues et al. 2013). In the present study, the four transformants of $F$. verticillioides expressing GFP or DsRed did not differ from the wild-type strain in the production of extracellular enzymes (i.e., protease, pectinase, amylase, and cellulose) and the production of FB. However, reductions in the growth of some transformants compared with the wild-type strain, in terms of the diameters and daily increases of colonies, were observed, especially on the acidic plates at $\mathrm{pH} 4.0$ and 5.5 (for

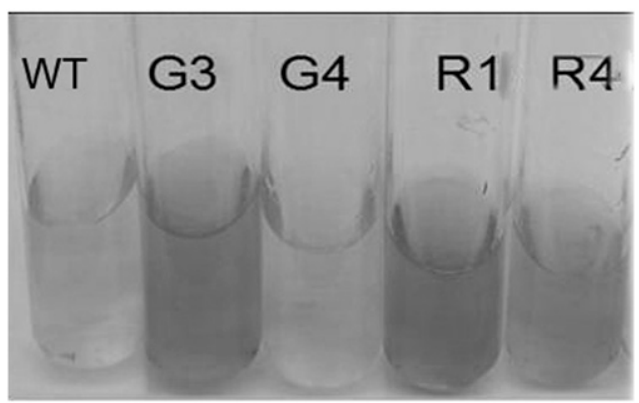

Fig. 4. Comparison of the color of the crude extracts of fumonisin B from the cultures of each transformant and the wild-type strain. G3 and G4 = the transformants labeled with green fluorescent protein (GFP), R1 and R4 = the transformants labeled with DsRed, and WT = the wild-type Fusarium verticillioides.

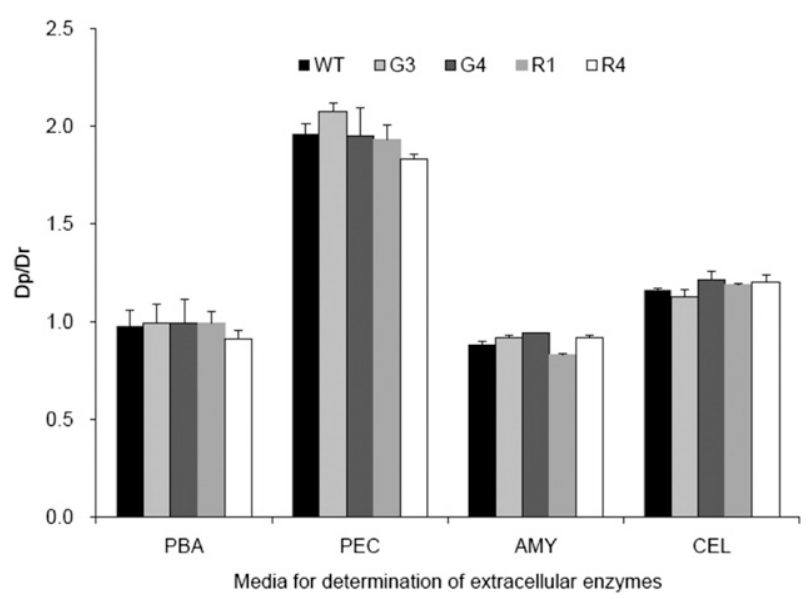

Fig. 5. Comparison of extracellular enzyme production by the transformants and the wild-type strain of Fusarium verticillioides. PBA = Capzek salt + nonfat-dried milk medium for determining proteinase metabolism, PEC = Capzek + pectin for determining pectinase, AMY = Capzek + starch for determining amylase, and CEL $=$ Capzek + carboxymethyl cellulose medium for determining cellulase. Data presented in the figure represent the ratios of the zone of transparency (Dp) to radius (Dr) of colony. Error bars indicate the standard errors. example, transformants G3 and R4). The growth of transformant R1 did not appear to be affected by the introduction of DsRed protein until the $\mathrm{pH}$ values were brought to 10 or 11.5 (Table 3). The $\mathrm{pH}$ values of nutrient media had a significant impact on the colony expansion of the transformant and the wild-type strains. The colony diameters and daily increases of all the strains at lower $\mathrm{pH}$ values were less than those at higher $\mathrm{pH}$ values. Similarly, Marín et al. (1995) reported that optimal $\mathrm{pH}$ for the growth of $F$. moniliforme (=F. verticillioides) was $\mathrm{pH} 7$ and the growth of this fungus was reduced at lower $\mathrm{pH}$ values. It was reported that the $\mathrm{pH}$ values for the vacuole and cytoplasm of maize were 5.5 and 7.1 (Roberts et al. 1980). The $\mathrm{pH}$ of root tissues ground in water was measured to range between 4.1 and 5.5 for different maize genotypes (L. Wu and H. J., $\mathrm{Li}$, unpublished data). Moreover, root exudation and respiration of plant root and microorganisms can cause the build-up of the $\mathrm{CO}_{2}$ concentration, which, in turn, results in a decrease in the rhizospheric $\mathrm{pH}$ (Hinsinger et al. 2003). The acidic environment of maize roots may have an influence on the growth of the transformants and also on the wild-type strain. to a lesser degree inside the root tissues. Wilke et al. (2007) reported that a GFP transformant of $F$. verticillioides TXI-79, which was produced by the PEG method, had a rate of growth similar to that of a wild-type strain and concluded that the ability to colonize maize in that transformant was not affected by the expression of GFP. The transformant strain TXI-79 was used to study seed transmission and systemic infection by $F$. verticillioides in maize (Murillo-Williams and Munkvold 2008; Wilke et al. 2007). In the current study, it was possible to select the fluorescent-protein-expressing strains that have growth properties similar to those of the wild-type strain, because certain transformants, such as strains G4 and R1, had colony diameters and daily increases similar to the wild-type strain (Table 2).

Based on the recovery from the highest internode of plants inoculated with the GFP-transformed strain TXI-79 and the wild-type strain M-8114, Wilke et al. (2007) concluded that the colonization of maize stalks was not affected by the GFP insertion. Oren et al. (2003) selected a GFP-expressing strain of $F$. verticillioides, gf12, generated by the PEG method, which was as infective as the wild-type strain during early events of the interactions between the fungus and maize.
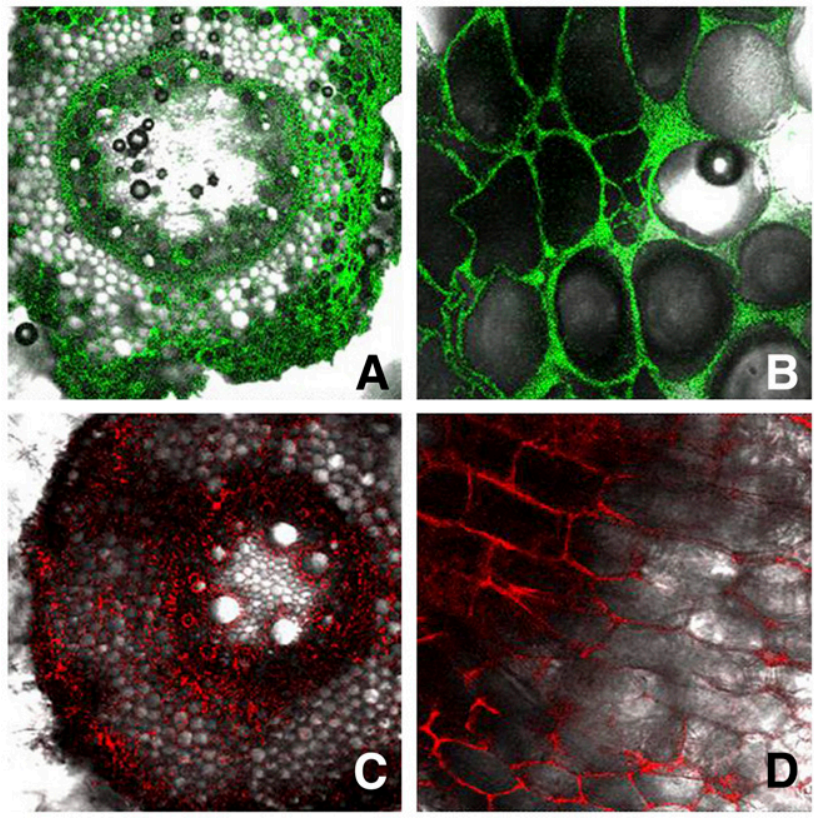

Fig. 6. Colonization of $\mathbf{A}$ and $\mathbf{B}$, green fluorescent protein (GFP)-labeled and $\mathbf{C}$ and D, DsRed-labeled Fusarium verticillioides on the roots of maize inbred line Huangzaosi under a confocal laser-scanning microscope. 
In this study, the four transformants expressing either the GFP or DsRed fluorescent proteins were able to colonize maize roots. However, the CFU values produced by the infection of the transformants were significantly less than those of the wild-type strain at different sampling dates. This result demonstrates that the insertion of the GFP and DsRed transformation cassettes resulted in a reduction in the efficiency of infection. Analysis of the insertion sites of these transformants indicated that the target gene DsRed was inserted in a gene encoding a nitrogen fixation protein or a hypothetical protein in the two transformants expressing DsRed protein but the gfp gene was not inserted into a functional protein coding sequence. This information does not indicate that the disruption of the functional genes was the major reason for reduction in the colonization on maize roots by these transformants. The disruption of a class I chitin synthase gene caused not only the reduction in chitin synthase activity but also changes in chitin content, conidiation, and macroconidium length in Verticillium dahlia Kleb. (Xu et al. 2010b). In the transformants of the lichen fungus Umbilicaria muehlenbergii (Ach.) Tuck. expressing GFP protein generated by ATMT, putative mutants showed phenotypic variation in colony color, size, or morphology. Those mutants proved to have no significant similarities to any known genes in the GenBank database (Park et al. 2013).

The random integration of an autofluorescent gene cassette is a normal event in ATMT. However, the integration site bias increases the possibility that the T-DNA may disrupt a functional gene and reduce the fitness of the fungus (Frandsen 2011). The transformation itself may also have a pleotropic effect on fungal fitness, which might explain the influence of the integration of GFP on the growth and production of ochratoxin A in A. carbonarius (CrespoSempere et al. 2011). The random insertion of the T-DNA into the fungal genome makes it difficult to predict the precise effects of the autofluorescent proteins on the fitness of fungi. Targeted functional gene interruption can be realized by the construction of vectors used in the ATMT strategy (Frandsen 2011; Michielse et al. 2005). Vectors have been constructed for Fusarium spp. to develop nearly isogenic strains and to eliminate the possibility of unintentional disruption of unknown genes in the genome (Sørensen et al. 2012; $\mathrm{Xu}$ et al. 2010b). This strategy is helpful in elucidating the effects of the autofluorescent proteins on the variation in the fungal growth and pathogenicity.

Binary vectors are normally used for fungal transformation by means of A. tumefaciens. An appropriate selection marker is a guarantee for successful transformation. However, concern is increasing regarding the potential impacts of the selection markers on the phenotypic performance and fitness of the transformants (Frandsen 2011). Genes in the recipient genomes can be inactivated by the insertion of a T-DNA containing only a selection marker. The antibiotic selection markers, which are currently used for screening transgenic organisms, have also caused environmental and food safety problems (Scutt et al. 2002). Recently, a purple chromophrotein (CP) was isolated from Stichodactyla haddoni Sarille-Kent and designated shCP, which allows the visual selection of transformants without imposing any environmental and safety problems because it is biodegradable and is derived from a marine organism (Shih et al. 2015). Nevertheless, the impact of this protein on the fitness of filamentous fungi is not known. In plants, an antibiotic marker-free transformation technique is available (Ferradini et al. 2016). Binary vectors that permit the removal of the selectable markers from the transformation cassettes are not currently applicable for fungal transformation (Frandsen 2011). However, the removal of the antibiotic markers is possible using the strategies of split-marker system (Kück and Hoff 2010) and Cre-lox-based system (Leibig et al. 2008). Alternatively, a technique that directly changes the fungal genome by specific insertion, replacement, or modifications through exactly changing a single particular base pair of a targeted gene but leaving no selectable markers or other extraneous DNA has been used in F. graminearum (Watson and Wang 2012).
It was generally observed that not all the phenotypic mutants were associated with the transformation of T-DNA (Michielse et al. 2005). On the other hand, the introduction of the autofluorescent proteins GFP and DsRed did not have any impact on the fitness of transformants in F. oxysporum f. sp. lycopersici (Nahalkova and Fatehi 2003) or Acremonium strictum W. Gams (Grunewaldt-Stöcker et al. 2007). As was the case in the present study, the amount of phenotypic variation in different transformants in $F$. verticillioides was not identical. Estimation of the proportion of the mutant phenotypes that resulted from a T-DNA insertion event is difficult. Thus, it is prudent to increase the likelihood that the transformants are representatives of the recipient fungal strains by performing comparative studies when they are used in the studies of fungus-plant interactions.

The intention of the present study was to generate the GFP- or DsRed-labeled $F$. verticillioides strains for studying the colonization of this fungus on maize (Wu et al. 2011, 2013). The identification of the transformants with altered fitness provides an opportunity for studying the effects of the integration of the autofluorescent proteins in view of the functional genomics. Further study is needed to design vectors that can ectopically express from the predetermined locus, for example, the nitrogen fixation protein NifU, to produce isogenic strains. However, the ectopic integration by means of ATMT occurs rarely, as shown in $F$. graminearum Schwabe by Frandsen (2011).

\section{ACKNOWLEDGMENTS}

We thank M. Franceschetti, John Inner Center, UK for kindly providing the plasmids pCAMBGFP and pCAMDsRed, which were used in genetic transformation; Y. Zhang and G. Li, Hebei Academy of Agricultural and Forestry Sciences, China, for analyzing the insertion sites of the transformants; and the Agricultural Science and Technology Program for Innovation Team of Chinese Academy of Agricultural Sciences for providing financial support for this study.

\section{LITERATURE CITED}

Bacon, C. W., and Hinton, D. M. 1996. Symptomless endophytic colonization of maize by Fusarium moniliforme. Can. J. Bot. 74:1195-1202.

Baird, G. S., Zacharias, D. A., and Tsien, R. Y. 2000. Biochemistry, mutagenesis, and oligomerization of DsRed, a red fluorescent protein from coral. Proc. Natl. Acad. Sci. USA 97:11984-11989.

Betts, M. F., Tucher, S. L., Galadima, N., Meng, Y., Patel, G., Li, L., Donofrio, N., Floyd, A., Nolin, S., Brown, D., Alejandra Mandel, M., Mitchell, T. K., Xu, J. R., Dean, R. A., Farman, M. L., and Orbach, M. J. 2007. Development of a high throughput transformation system for insertional mutagenesis in Magnaporthe oryzae. Fungal Genet. Biol. 44: 1035-1049.

Bourett, T. M., Sweigard, J. A., Czymmek, K. J., Carroll, A., and Howard, R. J. 2002. Reef coral fluorescent protein for visualizing fungal pathogens. Fungal Genet. Biol. 37:211-220.

Bundock, P., den Dulk-Ras, A., Beijersbergen, A., and Hooykaas, P. J. 1995. Trans-kingdom T-DNA transfer from Agrobacterium tumefaciens to Saccharomyces cerevisiae. EMBO J. 14:3206-3214.

Crespo-Sempere, A., López-Pérez, M., Martínez-Culebras, P. V., and González-Candelas, L. 2011. Development of a green fluorescent tagged strain of Aspergillus carbonarius to monitor fungal colonization in grapes. Int. J. Food Microbiol. 148:135-140.

Dandie, C. E., Larrainzar, E., Mark, G. L., O’Gara, F., and Morrissey, J. P. 2005. Establishment of DsRed.T3_S4T as an improved autofluorescent marker for microbial ecology application. Environ. Microbiol. 7:1818-1825.

de Groot, M. J. A., Bundock, P., Hooykaas, P. J. J., and Beijersbergen, A. G. M. 1998. Agrobacterium tumefaciens-mediated transformation of filamentous fungi. Nat. Biotechnol. 16:839-842.

Di Pietro, A., and Roncero, M. I. 1998. Cloning, expression, and role in pathogenicity of $p g 1$ encoding the major extracellular endopolygalacturonase of the vascular wilt pathogen Fusarium oxysporum. Mol. PlantMicrobe Interact. 11:91-98.

Dobinson, K. F., Lecomte, N., and Lazarovits, G. 1997. Production of an extracellular trypsin-like protease by the fungal plant pathogen Verticillium dahliae. Can. J. Microbiol. 43:227-233.

Duncan, K. E., and Howard, R. J. 2010. Biology of maize kernel infection by Fusarium verticillioides. Mol. Plant-Microbe Interact. 23:6-16. 
Dunn, A. R., Fry, B. A., Lee, T. Y., Conley, K. D., Balaji, V., Fry, W. E., McLeod, A., and Smart, C. D. 2013. Transformation of Phytophthora capsici with genes for green and red fluorescent protein for use in visualizing plant-pathogen interactions. Australas. Plant Pathol. 42:583-593.

Eckert, M., Maguire, K., Urban, M., Foster, S., Fitt, B., Lucas, J., and Hammond-Kosack, K. 2005. Agrobacterium tumefaciens-mediated transformation of Leptosphaeria spp. and Oculimacula spp. with the reef coral gene DsRed and the jellyfish gene gfp. FEMS Microbiol. Lett. 253:67-74.

Ferradini, N., Giancaspro, A., Nicolia, A., Gadaleta, A., Veronesi, F., and Rosellini, D. 2016. Efficient, antibiotic marker-free transformation of a dicot and a monocot crop with glutamate 1-semialdehyde aminotransferase selectable marker genes. Methods Mol. Biol. 1385:89-98.

Frandsen, R. J. N. 2011. A guide to binary vectors and strategies for targeted genome modification in fungi using Agrobacterium tumefaciens-mediated transformation. J. Microbiol. Methods 87:247-262.

Füchslin, H. P., Rüegg, I., van der Meer, J. R., and Egli, T. 2003. Effect of integration of a GFP reporter gene on fitness of Ralstonia eutropha during growth with 2,4-dichlorophenoxyacetic acid. Environ. Microbiol. 5:878-887.

Glenn, A. E., Zitomer, N. C., MariZimeri, A., Williams, L. D., Riley, R. T., and Proctor, R. H. 2008. Transformation-mediated complementation of a FUM gene cluster deletion in Fusarium verticillioides restores both fumonisin production and pathogenicity on maize seedlings. Mol. Plant-Microbe Interact. 21:81-97.

Grimaldi, B., de Raaf, M. A., Filetici, P., Ottonello, S., and Ballario, P. 2005. Agrobacterium-mediated gene transfer and enhanced green fluorescent protein visualization in the mycorrhizal ascomycete Tuber borchii: A first step towards truffle genetics. Curr. Genet. 48:69-74.

Grunewaldt-Stöcker, G., Riediger, N., and Dietrich, C. 2007. Suitability of GFP-transformed isolates of the fungal root endophyte Acremonium strictum W. Gams for studies on induced Fusarium-wilt resistance in flax. Plant Root 1:46-56

Haghighi, M. Y.-P., Soltani, J., and Nazeri, S. 2013. A survey on optimization of Agrobacterium-mediated genetic transformation of the fungus Colletotrichum gloeosporioides. J. Cell Mol. Res. 5:35-41.

Herzog, E. W., Daniell, H., Singh, N. K., and Lemke, P. A. 1996. A comparative study on transformation of Aspergillus nidulans by microprojectile bombardment of conidia and a more conventional procedure using protoplasts treated with polyethylene glycol (PEG). Appl. Microbiol. Biotechnol. 45:333-337.

Hinsinger, P., Plassard, C., Tang, C., and Jaillard, B. 2003. Origins of rootmediated $\mathrm{pH}$ changes in the rhizosphere and their responses to environmental constraints: A review. Plant Soil 248:43-59.

Islam, M. N., Nizam, S., and Verma, P. K. 2012. A highly efficient Agrobacterium mediated transformation system for chickpea wilt pathogen Fusarium oxysporum f. sp. ciceri using DsRed-express to follow root colonization. Microbiol. Res. 167:332-338.

Jakobs, S., Subramaniam, V., Schönle, A., Jovin, T. M., and Hell, S. W. 2000. EGFP and DsRed expressing cultures of Escherichia coli imaged by confocal, two-photon and fluorescence lifetime microscopy. FEBS Lett. 479: 131-135.

Kant, P., Renprecht, Y., Martin, C. J., Islam, R., and Pauls, K. P. 2011. Disease resistance/pathology/Fusarium. Pages 729-743 in: Comprehensive Biotechnology, 2nd ed. Vol. 4: Agricultural and Related Biotechnologies. M. Moo-Young, ed. Elsevier B.V.

Köhl, J., Lombaers, C., Moretti, A., Bandyopadhyay, R., Somma, S., and Kastelein, P. 2015. Analysis of microbial taxonomical groups present in maize stalks suppressive to colonization by Fusarium spp.: A strategy for the identification of potential antagonists. Biol. Control 83:20-28.

Kommedahl, T., and Windels, C. E. 1981. Root-, stalk-, and ear-infecting Fusarium species on corn in the USA. Pages 94-103 in: Fusarium: Diseases, Biology and Taxonomy. P. E. Nelson, T. A. Toussoun, and R. J. Cook, eds. Pennsylvania State University Press, University Park.

Kück, U., and Hoff, B. 2010. New tools for the genetic manipulation of filamentous fungi. Appl. Microbiol. Biotechnol. 86:51-62.

Lagopodi, A. L., Ram, A. F. J., Lamers, G. E. M., Punt, P. J., van den Hondel, C. A. M. J. J., Lugtenberg, B. J. J., and Bloemberg, G. V. 2002. Novel aspects of tomato root colonization and infection by Fusarium oxysporum f. sp. radicis-lycopersici revealed by confocal laser scanning microscopic analysis using the green fluorescent protein as a marker. Mol. PlantMicrobe Interact. 15:172-179.

Larrainzar, E., O'Gara, F., and Morrissey, J. P. 2005. Application of autofluorescent proteins for in situ studies in microbial ecology. Annu. Rev. Microbiol. 59:257-277.

Leibig, M., Krismer, B., Kolb, M., Friede, A., Götz, F., and Bertram, R. 2008. Marker removal in staphylococci via Cre recombinase and different lox sites. Appl. Environ. Microbiol. 74:1316-1323.

Li, S., Lygin, A., Zernova, O., Lozovaya, V., Hartman, G. L., and Widholm, J. 2008. Genotype response of soybean (Glycine max) whole plants and hairy roots to Fusarium solani f. sp. glycines infection. Soybean Sci. 27: 275-282.
Lorang, J. M., Tuori, R. P., Martinez, J. P., Sawyer, T. L., Redman, R. S., Rollins, J. A., Wolpert, T. J., Johnson, K. B., Rodriguez, R. J., Dickman, M. B., and Ciuffetti, L. M. 2001. Green fluorescent protein is lighting up fungal biology. Appl. Environ. Microbiol. 67:1987-1994.

Lübeck, M., Knudsen, I. M. B., Jensen, B., Thrane, U., Janvier, C., and Funck Jensen, D. F. 2002. GUS and GFP transformation of the biocontrol strain Clonostachys rosea IK726 and the use of these marker genes in ecological studies. Mycol. Res. 106:815-826.

Marín, S., Sanchis, V., and Magan, N. 1995. Water activity, temperature, and $\mathrm{pH}$ effects on growth of Fusarium moniliforme and Fusarium proliferatum isolates from maize. Can. J. Microbiol. 41:1063-1070.

Michielse, C. B., Hooykaas, P. J. J., van den Hondel, C. A. M. J. J., and Ram, A. F. J. 2005. Agrobacterium-mediated transformation as a tool for functional genomics in fungi. Curr. Genet. 48:1-17.

Mikkelsen, L., Sarrocco, S., Lübeck, M., and Jensen, D. F. 2003. Expression of the red fluorescent protein DsRed-express in filamentous ascomycete fungi. FEMS Microbiol. Lett. 223:135-139.

Mullins, E. D., Chen, X., Romaine, P., Raina, R., Geiser, D. M., and Kang, S. 2001. Agrobacterium-mediated transformation of Fusarium oxysporum: An efficient tool for insertional mutagenesis and gene transfer. Phytopathology 91:173-180.

Murillo-Williams, A., and Munkvold, G. P. 2008. Systemic infection by Fusarium verticillioides in maize plants grown under three temperature regimes. Plant Dis. 92:1695-1700.

Nahalkova, J., and Fatehi, J. 2003. Red fluorescent protein (DsRed2) as a novel reporter in Fusarium oxysporum f. sp. lycopersici. FEMS Microbiol. Lett. 225:305-309.

Nigro, F., Finetti, M. M., and Gallitelli, D. 1999. Transformation of Metschnikowia pulcherrima 320, biocontrol agent of storage rot, with the green fluorescent protein gene. J. Plant Pathol. 81:205-208.

Nizam, S., Singh, K., and Verma, P. K. 2010. Expression of the fluorescent proteins DsRed and EGFP to visualize early events of colonization of the chickpea blight fungus Ascochyta rabiei. Curr. Genet. 56:391-399.

Oren, L., Ezrati, S., Cohen, D., and Sharon, A. 2003. Early events in the Fusarium verticillioides-maize interaction characterized by using a green fluorescent protein-expressing transgenic isolate. Appl. Environ. Microbiol. 69:1695-1701.

Paparu, P., Macleod, A., Dubois, T., Coyne, D., and Viljoen, A. 2009. Efficacy of chemical and fluorescent protein markers in studying plant colonization by endophytic non-pathogenic Fusarium oxysporum isolates. BioControl 54:709-722.

Park, S.-Y., Jeong, M.-H., Wang, H.-Y., Kim, J. A., Yu, N.-H., Kim, S., Cheong, Y. H., Kang, S., Lee, Y.-H., and Hur, J.-S. 2013. Agrobacterium tumefaciens-mediated transformation of the lichen fungus, Umbilicaria muehlenbergii. PLoS One 8:e83896.

Pliego, C., Kanematsu, S., Ruano-Rosa, D., de Vicente, A., López-Herrera, C., Cazorla, F. M., and Ramos, C. 2009. GFP sheds light on the infection process of avocado roots by Rosellinia necatrix. Fungal Genet. Biol. 46: $137-145$

Puhalla, J. E., and Spieth, P. T. 1983. Heterokaryosis in Fusarium moniliforme. Exp. Mycol. 7:328-335.

Roberts, J. K. M., Ray, P. M., Wade-Jardetzky, N., and Jardetzky, O. 1980. Estimation of cytoplasmic and vacuolar $\mathrm{pH}$ in higher plant cells by ${ }^{31} \mathrm{P}$ NMR. Nature 283:870-872.

Rodrigues, M. B. C., Favaro, L. C. D., Pallu, A. P. D., Ferreira, A., Sebastianes, F. D., Rodrigues, M. J. C., Sposito, M. B., De Araujo, W. L., and Pizzirani-Kleiner, A. A. 2013. Agrobacterium-mediated transformation of Guignardia citricarpa: An efficient tool to gene transfer and random mutagenesis. Fungal Biol. 117:556-568.

Sagaram, U. S., Shaw, B. D., and Shim, W. B. 2007. Fusarium verticillioides GAP1, a gene encoding a putative glycolipid-anchored surface protein, participates in conidiation and cell wall structure but not virulence. Microbiology 153:2850-2861.

Sarrocco, S., Falaschi, N., Vergara, M., Nicoletti, F., and Vannacci, G. 2007. Use of Fusarium oxysporum f. sp. dianthi transformed with marker genes to follow colonization of carnation roots. J. Plant Pathol. 89:47-54

Schuster, M., Kilaru, S., Guo, M., Sommerauer, M., Lin, C., and Steinberg, G. 2015. Red fluorescent proteins for imaging Zymoseptoria tritici during invasion of wheat. Fungal Genet. Biol. 79:132-140.

Scutt, C. P., Zubko, E., and Meyer, P. 2002. Techniques for the removal of marker genes from transgenic plants. Biochimie 84:1119-1126.

Sesma, A., and Osbourn, A. E. 2004. The rice leaf blast pathogen undergoes developmental processes typical of root-infecting fungi. Nature 431:582-586.

Shih, C. H., Chen, H.-Y., Lee, H.-C., and Tsai, H. J. 2015. Purple chromoprotein gene serves as a new selection marker for transgenesis of the microalga Nannochloropsis oculata. PLoS One 10:e0120780.

Siqueira, C. D. S., Machado, J. D. C., Corrêa, C. L., and Barrocas, E. N. 2014. Colonization of maize seeds by two species of Stenocarpella transformed 
with fluorescent proteins and assessed through scanning electron microscopy. J. Seed Sci. 36:168-177.

Skadsen, R. W., and Hohn, T. A. 2004. Use of Fusarium graminearum transformed with $g f p$ to follow infection patterns in barley and Arabidopsis. Physiol. Mol. Plant Pathol. 64:45-53.

Sørensen, J. L., Hansen, F. T., Sondergaard, T. E., Staerk, D., Lee, T. V., Wimmer, R., Klitgaard, L. G., Purup, S., Giese, H., and Frandsen, R. J. N. 2012. Production of novel fusarielins by ectopic activation of the polyketide synthase 9 cluster in Fusarium graminearum. Environ. Microbiol. 14: 1159-1170.

Srivastava, P., Mailhot, D. J., Leite, B., Marois, J. J., Wright, D. L., and Nichols, R. L. 2010. Fusarium verticillioides (Saccardo) Nirenberg associated with hardlock of cotton. Curr. Microbiol. 61:79-84.

Steel, R. G. D., and Torrie, J. H. 1960. Page 481 in: Principles and Procedures of Statistics. McGraw-Hill, New York.

Sureka, S., Chakravorty, A., Holmes, E. C., Spassibojko, O., Bhatt, N., Wu, D. L., and Turgeon, B. G. 2014. Standardization of functional reporter and antibiotic resistance cassettes to facilitate the genetic engineering of filamentous fungi. ACS Synth. Biol. 3:960-962.

van der Does, H. C., Duyvesteijn, R. G. E., Goltstein, P. M., van Schie, C. C. N., Manders, E. M. M., Cornelissen, B. J. C., and Rep, M. 2008. Expression of effector gene SIX1 of Fusarium oxysporum requires living plant cells. Fungal Genet. Biol. 45:1257-1264.
Watson, R. J., and Wang, S. 2012. A method for making directed changes to Fusarium graminearum genome without leaving markers or other extraneous DNA. Fungal Genet. Biol. 49:556-566.

Wilke, A. L., Bronson, C. R., Tomas, A., and Munkvold, G. P. 2007. Seed transmission of Fusarium verticillioides in maize plants grown under three different temperature regimes. Plant Dis. 91:1109-1115.

Wu, L., Wang, X. M., Xu, R. Q., and Li, H. J. 2011. Root infection and systematic colonization of DsRed-labelled Fusarium verticillioides in maize. Acta Agron. Sin. 37:793-802.

Wu, L., Wang, X. M., Xu, R. Q., and Li, H. J. 2013. Difference of resistant and susceptible maize in systematic colonization as revealed by DsRed-labeled Fusarium verticillioides. Crop J. 1:61-69.

Xu, R. Q., Wang, J. N., Chen, J. Y., and Dai, X. F. 2010a. Analysis of T-DNA insertional flanking sequence and mutant phenotypic characteristics in Verticillium dahlia. Sci. Agric. Sin. 43:489-496.

Xu, Y. B., Li, H. P., Zhang, J. B., Song, B., Chen, F. F., Duan, X. J., Xu, H. Q., and Liao, Y. C. 2010b. Disruption of the chitin synthase gene CHS1 from Fusarium asiaticum results in an altered structure of cell walls and reduced virulence. Fungal Genet. Biol. 47:205-215.

Zhang, L., Yang, J., Niu, Q., Zhao, X., Ye, F., Liang, L., and Zhang, K. Q. 2008. Investigation on the infection mechanism of the fungus Clonostachys rosea against nematodes using the green fluorescent protein. Appl. Microbiol. Biotechnol. 78:983-990. 